J. Braz. Chem. Soc., Vol. 15, No. 1, 146-149, 2004.

Printed in Brazil - (C2004 Sociedade Brasileira de Química

0103 - $5053 \$ 6.00+0.00$

\title{
Luxenchalcone, a New Bichalcone and other Constituents from Luxemburgia octandra
}

\author{
Mário G. de Carvalho ${ }^{*, a}$, Cassia C. Fernandes Alves ${ }^{a}$, Kedma G. S. da Silva ${ }^{a}$, Marcos N. Eberlin ${ }^{b}$ \\ and Alceni A. Werle \\ ${ }^{a}$ Departamento de Química, ICE, Universidade Federal Rural do Rio de Janeiro, 23851-970 Seropédica - RJ, Brazil \\ ${ }^{b}$ Instituto de Química, Universidade Estadual de Campinas, CP 6154, 13084-971 Campinas - SP, Brazil \\ ${ }^{c}$ Departamento de Química, ICEB, Universidade Federal de Ouro Preto, 35400-000 Ouro Preto - MG, Brazil
}

\begin{abstract}
O fracionamento cromatográfico dos extratos de folhas e galhos de Luxemburgia octandra (Ochnaceae) resultou no isolamento de: isoliquiritigenina, 3'-hidroxiisoliquiritigenina, $\beta$-sitosterol, estigmasterol, lupeol, ácido betulínico, o biflavonóide, 4',5,7-triidroxiflavona-(3' $\rightarrow \mathrm{O} \rightarrow 4$ '”)-5",7"'-

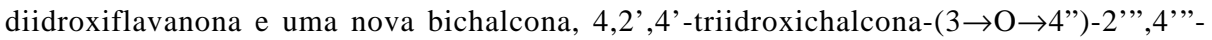
diidroxichalcona (luxenchalcona). As estruturas desses compostos foram estabelecidas com base na análise dos dados espectrométricos de IV, EM e RMN incluindo experimentos 2D das substâncias naturais e do derivado metilado da luxenchalcona.
\end{abstract}

Chromatographic fractionation of leaves and branches extracts from Luxemburgia octandra (Ochnaceae) afforded isoliquiritigenin, 3'-hydroxyisoliquiritigenin, $\beta$-sitosterol, stigmasterol, lupeol, betulinic acid, the biflavonoid, 4',5,7-trihydroxyflavone-(3' $\rightarrow \mathrm{O} \rightarrow 4$ '")-5",7"-dihydroxyflavanone

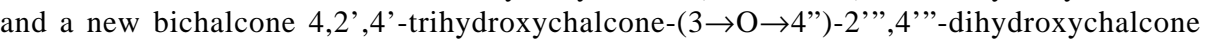
(luxenchalcone). The structures were established from analysis of IR, MS and NMR spectral data, including 2D-NMR experiments of the natural substances and of the luxenchalcone methyl derivative.

Keywords: Luxemburgia octandra, Ochnaceae, flavonoids, bichalcone, terpenoids

\section{Introduction}

Luxemburgia octandra St. Hil (Ochnaceae) is a shrub or small tree distributed throughout the Brazilian Southeastern region. Ochnaceae is a large tropical family including $\mathrm{ca}$. 40 genera and 600 species with the greatest concentration in tropical South America. ${ }^{1}$ In the course of our phytochemical and pharmacological investigations of Brazilian plants, we have studied species of both Ouratea and Luxemburgia genera, in which the presence of biflavonoids was observed ${ }^{2-5}$ along with their antitumoral activities. ${ }^{6,7}$ The biflavonoid 4',5,7-trihydroxyflavone$(3 ' \rightarrow \mathrm{O} \rightarrow 4$ "')-5",7"-dihydroxyflavanone was isolated from Luxemburia noilis ${ }^{4}$ and from L. octandra (present work) have shown antitumoral activities. ${ }^{6}$ No previous work has been reported on L. octandra species.

* e-mail: mgeraldo@ufrrj.br

\section{Experimental}

General procedures

Melting points are uncorrected. IR spectra were recorded on Perkin-Elmer 1600/1605 FT-IR spectrophotometer using $\mathrm{KBr}$ disks or $\mathrm{NaCl}$ film. NMR spectra in $\mathrm{D}_{3} \mathrm{CCOCD}_{3}, \mathrm{CD}_{3} \mathrm{OD}$ or $\mathrm{CDCl}_{3}$ were recorded on Bruker $\left(200 \mathrm{MHz}\right.$ for ${ }^{1} \mathrm{H}$ and $50.3 \mathrm{MHz}$ for ${ }^{13} \mathrm{C}$ ) and on Jeol JNMGX-400 (400 MHz for ${ }^{1} \mathrm{H}$ and $100 \mathrm{MHz}$ for ${ }^{13} \mathrm{C}$ ) spectrometers using tetramethylsilane (TMS) as internal standard. Electron Ionization Mass Spectra (EIMS) were taken with Gas Chromatography coupled to a Mass Spectrometry (GC/MS) on Varian Saturn 2000 and high resolution electron spray ionization mass spectra (HRESIMS) was obtained with a VG 7070E - HF spectrometer. CC: silica gel (Merck and Aldrich 0.05-0.20 mm); TLC: silica gel H or $\mathrm{G}$ (Merck and Aldrich) was used to analyze the fractions collected from column chromatography (CC) with visualization by $\mathrm{UV}$ (254 and $366 \mathrm{~nm}$ ), $\mathrm{AlCl}_{3}$-EtOH (1\%) and exposure to iodine vapor. 


\section{Plant material}

Luxemburgia octandra St. Hil was collected in Morro de São Sebastião, Ouro Preto, Minas Gerais, Brazil and authenticated by the botanist Jorge L. Silva. A voucher specimen ( $\mathrm{N}^{\circ}$ 26197) is deposited at the OUPR-UFOP Herbarium, Instituto de Ciências Exatas e Biológicas of the Universidade Federal de Ouro Preto-MG, Brazil.

\section{Extraction and isolation}

Dried leaves $(621 \mathrm{~g})$ and branches $(1.865 \mathrm{Kg})$ were powdered and extracted with hexane and ethyl acetate by maceration at room temperature. The extracts were concentrated under vacuum to yield the residues $\mathrm{A}(6.1 \mathrm{~g})$, and B (10.4 g) from the leaves, C (4.8 g) and D (20.7 g) from the branches, respectively, with hexane and ethyl acetate. The residues $\mathrm{B}$ and $\mathrm{D}$ were dissolved in $\mathrm{H}_{2} \mathrm{O}$ / $\mathrm{CH}_{3} \mathrm{OH}(1: 1)$ and extracted with hexane/diethyl ether (1:1). These solvents were removed under vacuum and the hexane/diethyl ether fractions (B-1, $0.8 \mathrm{~g}$ ) and (D-1, 3.5 g) were successively filtered on sephadex LH-20 column using methanol as mobile phase. The collected fractions of B-1 (28 fractions, $50 \mathrm{ml}$ ) and D-1 (25 fractions, $50 \mathrm{ml}$ ) were analyzed by silica gel TLC. Fractions $15-17$ of the B-1 gave biflavonoid 4',5,7-trihydroxy-flavone-(3' $\rightarrow O \rightarrow 4$ '")5 ", 7"-dihydroxyflavanone [2, $40 \mathrm{mg}$, m.p. $220^{\circ} \mathrm{C},[\mathrm{a}]_{\mathrm{D}}{ }^{20}+$ $\left.1.8\left(\mathrm{Me}_{2} \mathrm{CO}, \mathrm{c}=0.33\right)\right]$; fractions $20-24$ yielded a mixture of chalcones isoliquiritigenin (3) and 3'-hydroxyisoliquiritigenin (4) (20 mg, gum). The fractions collected from the column of D-1 have impure compound 1 which were crystallized in acetone/ethyl acetate do yield pure compound 1 (yellow crystals, $300 \mathrm{mg}, \mathrm{mp} 172^{\circ} \mathrm{C}$ ). Product $1 \mathrm{a}$ (yellow crystals, $50 \mathrm{mg}$, mp $168^{\circ} \mathrm{C}$ ) was obtained by treating a methanol solution of $1(50 \mathrm{mg})$ with ethereal diazomethane. The residue $\mathrm{C}$ was dissolved in methanol and successively submitted to column chromatography of sephadex LH-20 using methanol as mobile phase. Fraction C-10/14 yielded steroids mixture, sitosterol and stigmasterol $(50 \mathrm{mg})$; fractions $\mathrm{C}-18 / 19$ and $\mathrm{C}-22 / 27$ gave the triterpene lupeol $\left(20 \mathrm{mg}, \mathrm{mp} 202{ }^{\circ} \mathrm{C}\right)$ and betulinic acid $\left(30 \mathrm{mg}, \mathrm{mp} 295^{\circ} \mathrm{C}\right)$, respectively.

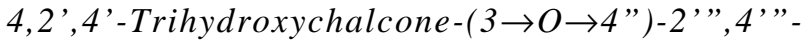
dihydroxychalcone (luxenchalcone), (1)

IR $(\mathrm{KBr}) v_{\max } / \mathrm{cm}^{-1}: 3497,1630,1510,1432,1289$, 1225, 974, 837, 802. ${ }^{1} \mathrm{H} \mathrm{NMR}\left(\mathrm{D}_{3} \mathrm{CCOCD}_{3}, 200 \mathrm{MHz}\right)$ and ${ }^{13} \mathrm{C} \mathrm{NMR}\left(\mathrm{D}_{3} \mathrm{CCOCD}_{3}, 50.3 \mathrm{MHz}\right.$ ) (Table 1). HRESIMS/ MS: $m / z$ (rel. int.) $510.0584\left[\mathrm{M}^{+\bullet}, 15\right.$ (calcd 510.131467 for $\mathrm{C}_{30} \mathrm{H}_{22} \mathrm{O}_{8}$ )], 399.0673 (10), 373.0878 (100), 355.0829 (23), 135.0125 (53).

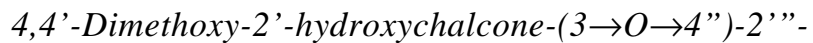
hydroxy-4"'-methoxychalcone (luxenchalconetrimethylether), (1a)

IR $(\mathrm{KBr}) v_{\max } / \mathrm{cm}^{-1}: 3410,2923,2851,1638,1562$, 1508, 1461, 1361, 1270, 1227, 1124, 972, 842. ${ }^{1} \mathrm{H}$ NMR $\left(\mathrm{CDCl}_{3}, 400 \mathrm{MHz}\right)$ and ${ }^{13} \mathrm{C} \mathrm{NMR}\left(\mathrm{CDCl}_{3} 100 \mathrm{MHz}\right)$ (Table 1). EIMS $m / z$ (rel. int.) $552\left(\mathrm{M}^{+}, 33 \%, \mathrm{C}_{33} \mathrm{H}_{28} \mathrm{O}_{8}\right), 401$ (65), $151(100)$.

\section{Results and Discussion}

The known natural compounds $\beta$-sitosterol, stigmasterol, ${ }^{10,11}$ lupeol, ${ }^{12}$ betulinic acid, ${ }^{13}$ isoliquiritigenin (3), ${ }^{8} 3$-hydroxy-isoliquiritigenin (4) ${ }^{9}$ and 4',5,7trihydroxy-flavone-(3' $\rightarrow \mathrm{O} \rightarrow 4$ '" ')-5", 7'"-dihydroxyflavanone $(2)^{4,14}$ were identified mainly by ${ }^{1} \mathrm{H}$ and ${ }^{13} \mathrm{C}$ NMR spectral analyses besides comparison with literature data. ${ }^{4,5,8-14}$<smiles>[R]Oc1ccc(/C=C/C(=O)c2ccc([R20])cc2O)cc1Oc1ccc(/C=C/C(=O)c2ccc(Oc3ccccc3)cc2O)cc1</smiles><smiles>O=C1C[C@H](c2ccc(Oc3cc(-c4cc(=O)c5c(O)cc(O)cc5o4)ccc3O)cc2)Oc2cc(O)cc(O)c21</smiles><smiles>[R]c1cc(/C=C/C(=O)c2ccc(O)cc2O)ccc1O</smiles>

Compound 1 gave a positive test with $\mathrm{AlCl}_{3}-\mathrm{EtOH}$ reagent, which confirmed the presence of a flavonoid. The IR spectrum showed bands at $3497\left(v_{\mathrm{O}-\mathrm{H}}\right), 1630\left(v_{\mathrm{C}=\mathrm{O}}\right)$ and $1510,1432 \mathrm{~cm}^{-1}$ attributed to aromatic ring. The 1D and 2D ${ }^{1} \mathrm{H}$ NMR spectra showed signals of three ABC systems, $\delta 6.34(\mathrm{~d}, 1 \mathrm{H}), 6.36(\mathrm{~d}, 1 \mathrm{H}), 6.46(\mathrm{dd}, 2 \mathrm{H}), 8.10(\mathrm{~d}, 2 \mathrm{H})$ and $7.09(\mathrm{~d}, 1 \mathrm{H}), 7.57(\mathrm{dd}, 1 \mathrm{H})$ and $7.69(\mathrm{~d}, 1 \mathrm{H})$ and signals of 
Table 1. ${ }^{1} \mathrm{H}$ and ${ }^{13} \mathrm{C}$-NMR spectral data $(\delta \mathrm{ppm})$ of compound $\mathbf{1}\left[\left(\mathrm{CD}_{3}\right)_{2} \mathrm{CO}, 200\right.$ and 50,3 MHz] and of its methyl derivative 1a $\left(\mathrm{CDCl}{ }_{3}, 400\right.$ and $100 \mathrm{MHz}$ )

\begin{tabular}{|c|c|c|c|c|}
\hline \multirow[t]{2}{*}{$\mathrm{C}$} & \multicolumn{2}{|c|}{1} & \multicolumn{2}{|c|}{$1 \mathbf{a}$} \\
\hline & $\delta_{\mathrm{H}}, \mathrm{m}, \mathrm{J}(\mathrm{Hz})$ & $\delta_{\mathrm{C}}$ & $\delta_{\mathrm{H}}, \mathrm{m}, \mathrm{J}(\mathrm{Hz})$ & $\delta_{\mathrm{C}}$ \\
\hline 1 & - & 128.4 & - & 128.4 \\
\hline 2 & $7.69(\mathrm{~d}, 2.3)$ & 122.6 & $7.43(\mathrm{~d}, 2.2)$ & 121.1 \\
\hline 3 & - & 144.0 & - & 144.0 \\
\hline 4 & - & 152.8 & - & 153.8 \\
\hline 5 & $7.09(\mathrm{~d}, 8.3)$ & 118.2 & $7.06(\mathrm{~d}, 8.4)$ & 112.9 \\
\hline 6 & $7.57(\mathrm{dd}, 8.3 ; 2.3)$ & 128.4 & $7.49(\mathrm{dd}, 8.4 ; 2.2)$ & 127.6 \\
\hline 1 , & - & 114.2 & - & 114.1 \\
\hline 2 , & - & 165.6 & - & 166.2 \\
\hline 3 , & $6.36(\mathrm{~d}, 2.7)$ & 103.7 & $6.47(\mathrm{~m})$ & 101.1 \\
\hline 4, & - & 167.3 & - & 166.6 \\
\hline 5, & $6.46(\mathrm{dd}, 8.7 ; 2.7)$ & 108.8 & $6.48(\mathrm{dd}, 9.0 ; 2.2)$ & 107.7 \\
\hline 6 , & $8.10(\mathrm{~d}, 8.7)$ & 130.9 & $7.81(\mathrm{~d}, 9.0)$ & 131.1 \\
\hline $1 "$ & - & 129.8 & - & 129.3 \\
\hline $2 "$ & $7.84(\mathrm{~d}, 8.7)$ & 129.8 & $7.62(\mathrm{~d}, 8.4)$ & 130.3 \\
\hline $3 "$ & $7.00(\mathrm{~d}, 8.7)$ & 117.2 & $6.97(\mathrm{~d}, 8.4)$ & 116.8 \\
\hline $4 "$ & - & 160.9 & - & 160.1 \\
\hline $5 "$ & $7.00(\mathrm{~d}, 8.7)$ & 117.2 & $6.97(\mathrm{~d}, 8.4)$ & 116.8 \\
\hline $6 "$ & $7.84(\mathrm{~d}, 8.7)$ & 129.8 & $7.62(\mathrm{~d}, 8.4)$ & 130.3 \\
\hline $1, "$, & - & 114.2 & - & 114.0 \\
\hline $2, "$ & - & 165.7 & - & 166.2 \\
\hline $3^{\prime \prime \prime}$ & $6.34(\mathrm{~d}, 2.7)$ & 103.7 & $6.47(\mathrm{~m})$ & 101.1 \\
\hline $4, "$, & - & 167.3 & - & 166.6 \\
\hline $5^{\prime,}$ & $6.46(\mathrm{dd}, 8.7 ; 2.7)$ & 108.8 & $6.46(\mathrm{dd}, 9.0 ; 2.2)$ & 107.7 \\
\hline $6 "$, & $8.10(\mathrm{~d}, 8.7)$ & 131.5 & $7.77(\mathrm{~d}, 9.0)$ & 131.1 \\
\hline $\mathrm{H}-\alpha$ & $7.85(\mathrm{~m})$ & 117.2 & $7.42(\mathrm{~d}, 15.4)$ & 118.8 \\
\hline $\mathrm{H}-\alpha$ & $7.85(\mathrm{~m})$ & 117.2 & $7.49(\mathrm{~d}, 15.4)$ & 119,0 \\
\hline $\mathrm{H}-\beta$ & $7.83(\mathrm{~m})$ & 143.2 & $7.81(\mathrm{~d}, 15.4)$ & 143.2 \\
\hline $\mathrm{H}-\beta$ & $7.83(\mathrm{~m})$ & 143.2 & $7.86(\mathrm{~d}, 15.4)$ & 143.8 \\
\hline HO & 13.58 (brs) & - & $13.49,13.45$ (brs) & - \\
\hline $\mathrm{C}=\mathrm{O}$ & - & 192.4 & - & $191.7,191.5$ \\
\hline MeO-4', 4',' & - & - & $3.86,3.85(\mathrm{~s})$ & $55.5 \times 2$ \\
\hline $\mathrm{MeO}-4$ & - & - & $3.88(\mathrm{~s})$ & 56.1 \\
\hline
\end{tabular}

AA'BB' at $\delta 7.00(\mathrm{~d}, 2 \mathrm{H})$ and $7.84(\mathrm{~d}, 2 \mathrm{H})$ of four aromatic rings. The additional signal at $\delta 13.58(\mathrm{~s}, 2 \mathrm{H})$ of two chelated hydroxyls and a multiplet at $\delta 7.83$ and 7.85 for hydrogens connected at a and $\beta$ carbons [ $\left(\delta_{\mathrm{CH}} 117.2\right.$ and 143.2 as observed in the $\left.{ }^{1} \mathrm{H},{ }^{13} \mathrm{C}-\mathrm{COSY}\left({ }^{1} J_{\mathrm{CH}}\right)\right]$ spectra, besides the $\delta_{\mathrm{C}=\mathrm{O}}$ at 192.4 , allowed to propose the chalcone structure (Table 1). These data and ${ }^{13} \mathrm{C}$ NMR (PND and DEPT) and ${ }^{1} \mathrm{H},{ }^{13} \mathrm{C}-\mathrm{COSY}\left({ }^{\mathrm{n}} J_{\mathrm{CH}} \mathrm{n}=1,2,3\right)$ spectra analysis were in agreement with two chalcones reported in the literature, isoliquiritigenin $(\mathbf{3})^{8}$ and 3-hydroxy-isoliquiritigenin (4). ${ }^{9}$ Treatment of $\mathbf{1}$ with diazomethane yielded $\mathbf{1 a}$ with three methoxy groups, besides two chelated hydroxy groups (Table 1). These information allowed us to propose the structure of a new bichalcone 4,2',4',2',,4'”pentahydroxy-3 $\rightarrow O \rightarrow 4$ "-bichalcone (1, named as luxenchalcone) (Table 1). The C-3-O-C-4" connection between the chalcone moieties was confirmed by a NOESY and NOEDIFF experiment of the derivative 1a. Irradiation at the methoxy groups showed NOE at $\delta 7.06(\mathrm{~d}, 8.4 \mathrm{~Hz}$, H-5), and at signals near $\delta 6.40$ (H-3', H-5', H-3'”, H-5'”).
These experiments did not show NOE at $\delta 7.43(\mathrm{~d}, \mathrm{H}-2)$ and 6.97 (d, H-3", H-5"). This result indicates that the positions 3 and 4" are not substituted with $\mathrm{OCH}_{3}$ groups. The $2 \mathrm{D}$ experiments $\left[{ }^{1} \mathrm{H},{ }^{1} \mathrm{H}-\mathrm{COSY},{ }^{1} \mathrm{H},{ }^{13} \mathrm{C}-\mathrm{COSY}\right.$ (HETCOR and COLOC of $\mathbf{1}$ and HMQC and HMBC of 1a)] were used to confirm the ${ }^{1} \mathrm{H}$ and ${ }^{13} \mathrm{C}$ chemical shifts of 1 and 1a (Table 1). The cross peaks observed in the HMBC spectra of 1a show long-range couplings of C-4 $\left(\delta_{\mathrm{C}} 153.8\right)$ with $\mathrm{OCH}_{3}(\delta 3.88)$, with $\mathrm{H}-2$ and with $\mathrm{H}-6\left({ }^{3} J_{\mathrm{CH}}\right)$ and also of C-3 $\left(\delta_{\mathrm{C}} 144.0\right)$ with $\mathrm{H}-2\left({ }^{2} J_{\mathrm{CH}}\right)$ and $\mathrm{H}-5\left({ }^{3} J_{\mathrm{CH}}\right)$ which were used to confirm the C-3-O-C-4" connection. The peaks at $m / z 552\left(\mathrm{M}^{+}, 33 \%, \mathrm{C}_{33} \mathrm{H}_{28} \mathrm{O}_{8}\right)$ in the LREIMS of $1 \mathbf{a}$ and the $\mathrm{m} / z 510.0584\left(\mathrm{M}^{+*}, 15 \% ; \mathrm{C}_{30} \mathrm{H}_{22} \mathrm{O}_{8}\right.$ requires 510.13147) in the HRESIMS of 1 were also used to confirm the proposed structure of this new bichalcone.

\section{Acknowledgements}

The authors are grateful to CNPq, CAPES and FAPERJ for scholarships and financial support, as well as to J. 
Schripsema and R. Braz-Filho, LCQUI-CCT-UENF, for the $400 \mathrm{MHz}$ NMR spectra of 1a.

\section{References}

1. Heywood, V. H.; Flowering Plants of the World, Oxford University Press: London, 1978, p. 82.

2. Moreira, I. C.; Sobrinho, D.C.; de Carvalho, M.G.; Braz-Filho, R.; Phytochemistry 1994, 25, 1567.

3. Moreira, I. C; Bastos, A. B.; de Carvalho, M. G.; Braz-Filho, R.; Phytochemistry 1999, 51, 833.

4. de Oliveira, M. C. C.; de Carvalho, M. G.; Silva, C. J. da; Werle, A. A.; J. Braz. Chem. Soc. 2002, 13, 119.

5. Velandia, J. R.; Carvalho, M. G. de; Braz-Filho, R.; Werle, A. A.; Phytochem. Anal. 2002, 13, 283.

6. de Carvalho, M. G.; Grynberg, N. F.; Echevarria, A. E.; de Oliveira, M. C. C. In Recent Progress in Medicinal Plants; Govil, J. N. ed.; Centre Res. Books (Org.): New Dehli, 2001, vol. 8 , p. 77.

7. Velandia, J. R.; de Carvalho, M. G.; Grynberg, N. F.; de Oliveira, M. C. C.; Moreira, I. C.; Braz-Filho, R.; Echevarria, A. E.; Braz. J. Med. Biol. Res. 2002, 35, 819.
8. Achenbach, H.; Stocher, M.; Constenia, M. A.; Phytochemistry 1988, 27, 1835.

9. Linuma, M.; Mizuno, M.; Phytochemistry 1989, 28, 681.

10. Chaurasia, N.; Wichtl, M.; J. Nat. Prod. 1987, 50, 881.

11. Dutra, N. N.; Alves, H. de M.; de Carvalho, M. G.; Braz-Filho, R.; Quim. Nova 1992, 15, 10

12. Sobrinho, D. C.; Hauptli, M. B.; Appolinário, E. V.; Kollenz, C. L. M.; de Carvalho, M. G.; Braz-Filho, R.; J. Braz. Chem. Soc. 1991, 2, 15.

13. Bilia, A. R.; Mendez, J.; Morelli, I.; Pharm. Acta Helv. 1996, $71,191$.

14. Geiger, H.; Quinn, C. Biflavonoids. In The Flavonoids: Advances in Research; Harborne, J. B., ed., Chapman \& Hall: London, 1982, p. 505.

15. Touchstone, J. C.; Dobbins, M. F.; Practice of Thin Layer Chromatography, John Wiley \& Sons Inc.: New York, 1983, p. 192.

Received: January 6, 2003

Published on the web: October 28, 2003

FAPESP helped in meeting the publication costs of this article. 